\title{
Aplikasi Pembelajaran Interaktif Ilmu Pengetahuan Sosial pada SMP Negeri 1 Carita
}

\author{
Sri Nurhayati ${ }^{1}$, Lamnidar Muharamsah ${ }^{2}$ \\ ${ }^{1}$ Prodi Sistem Komputer, Universitas Komputer Indonesia, Bandung \\ ${ }^{2}$ Prodi Teknik Informatika, Universitas Komputer Indonesia, Bandung \\ e-mail : sri.nurhayati@email.unikom.ac.id
}

Diterima: 08 April 2020; Direvisi: 03 Oktober 2020; Disetujui: 05 Oktober 2020

\begin{abstract}
Abstrak
Saat ini, pemanfaatan teknologi informasi sudah digunakan dalam bidang pendidikan. Komputer merupakan salah satu media yang dimanfaatkan sebagai alat bantu dalam sistem pembelajaran. Pembelajaran ilmu sosial adalah ilmu yang mempelajari ilmu-ilmu sosial berdasarkan fakta dan fenomena sosial. Selama ini, proses belajar mengajar untuk mata pelajaran IPS masih bersifat konvensional yaitu guru memberikan materti dari buku dan menggunakan metode ceramah tanpa alat peraga, hal ini disebabkan kurangnya alat peraga untuk mata pelajaran tersebut. Dari proses tersebut guru merasa kesulitan dan juga membutuhkan tenaga ekstra untuk menyampaikan materi ajar kepada siswa secara lisan sehingga pemahaman materi kepada siswa juga berkurang. Pada penelitian ini akan dibuat aplikasi pembelajaran interaktif untuk mata pelajaran IPS dengan menggunakan metode pengembangan aplikasi yaitu MDLC (Multimedia Development Life Cycle). Penelitian ini bertujuan untuk membuat aplikasi pembelajaran interaktif yang dapat digunakan sebagai alat bantu dalam proses pembelajaran IPS. Hasil penelitian menunjukkan bahwa secara fungsional aplikasi dapat digunakan, dan dapat meningkatkan minat belajar siswa serta membantu pemahaman mata pelajaran IPS.
\end{abstract}

Kata kunci: Ilmu pengetahuan sosial, pembelajaran interaktif, Multimedia Development Life Cycle

\begin{abstract}
Currently, the use of information technology has been used in the field of education. Computers are a medium that is used as a tool in the learning system. Social science learning is the study of social sciences based on social facts and phenomena. So far, the teaching and learning process for social studies subjects is still conventional, namely the teacher provides material from books and uses the lecture method without teaching aids, this is due to the lack of teaching aids for these subjects. From this process, the teacher finds it difficult and also requires extra energy to convey teaching material to students orally so that understanding of the material to students is also reduced. In this research, interactive learning applications will be made for social studies using the application development method, namely MDLC (Multimedia Development Life Cycle). This study aims to create interactive learning applications that can be used as a tool in the social studies learning process. The results show that functionally the application can be used, and can increase student interest in learning and help understanding social studies subjects.
\end{abstract}

Keywords: Social science, interactive learning, Multimedia Development Life Cycle 


\section{PENDAHULUAN}

Kegiatan yang dilakukan guru untuk transfer ilmu ke siswanya di kelas disebut dengan pembelajaran [1]. Saat ini teknologi informasi dapat dimanfaatkan untuk kebutuhan proses pembelajaran, misalnya dengan membuat pembelajaran interaktif dengan menggunakan bantuan komputer [2]. Ilmu pengetahuan sosial (IPS) adalah ilmu yang mempelajari beberapa peristiwa, fakta, konsep, dan generalisasi yang berkaitan dengan masalah - masalah sosial. Saat ini pembelajaran IPS di SMP Negeri 1 Carita bersifat konvensional, siswa diharuskan membaca materi dari buku, menggunakan alat peraga sederhana, menggunakan metode ceramah. Berdasarkan wawancara dengan guru yang mengajar pelajaran, guru marasakan kesulitan dan juga membutuhkan tenaga ekstra untuk menyampaikan materi ajar kepada siswa secara verbal. Ditambah lagi dengan minimnya alat peraga untuk menunjang pembelajaran, mengingat akan biaya yang tergolong besar jika harus menggunakan alat peraga. Salah satu kekurangan metode ceramah adalah membuat siswa kurang mendapat kesempatan untuk memberenikan diri dalam mengemukakan pendapatnya. Dengan melihat kekurangan tersebut, maka diperlukan sebuah media pembelajaran dimana mengubah metode yang sifatnya konvesional model pembelajaran multimedia interaktif [3].

Pembelajaran yang difokuskan pada siswa dan siswa dilibatkan langsung disetiap kegiatan pembelajaran di kelas disebut dengan jenis pembelajaran interaktif (Interactive Learning Model). Pada pembelajaran jenis ini, media yang digunakan adalah media computer. Interaktif yang dimaksud tidak hanya dititikberatkan pada hardware yang digunakan saja, melainkan bagaimana siswa dalam merespon stimulus yang ditampilkan oleh layar monitor komputer. Mutu dari pembelajaran ini sangat ditentukan dari kecanggihan aplikasi pembelajaran interaktif yang digunakan. [4][5].

Dari hasil penelitian sebelumnya tentang pembelajaran interaktif menghasilkan pembelajaran ini sangat efektif untuk membantu siswa dalam mempermudah materi yang diajarkan [6][7][8][9]. Salah satu metode untuk yang dapat dimanfaatkan untuk pengembangan aplikasi pembelajaran interaktif, yaitu metode Multimedia Development Life Cycle (MDLC). Pada metode tersebut terdapat enam tahapan yaitu: konsep (Concept), perancangan (Desain), pengumpulan bahan (Material Collecting), pembuatan (Assembly), pengujian (Testing), dan distribusi (Distribution) [10]. Beberapa penelitian yang menggunakan metode MDLC untuk pengembangan pembelajaran interaktif sudah dilakukakn dan hasilnya dengan metode ini dapat digunakan dan memudahkan pengembang dalam melakukakn pengembangan aplikasi [11][12][13].

Berdasarkan permasalahan tersebut, maka akan dibuat sebuah aplikasi pembelajaran interaktif mengunakan metode MDLC, dengan tujuan aplikasi yang dibuat dapat dijadikan sebagai alat bantu dalam proses pembelajar ilmu pelajaran sosial.

\section{METODE PENELITIAN}

Penetian ini menggunakan metode pembangunan perangkat lunak MDLC (Multimedia Development Life Cycle), tahapan pada metode ini dapat dilihat pada gambar 1. Pada tahapan concept akan dilakukan penentuan tujuan dari aplikasi yang akan dibuat dan siapa pengguna dari aplikasi tersebut. Pada tahap design (perancangan), dilakukan dengan membuat spesifikasi tentang arsitektur program, desain, dan bahan atau material pendukung yang digunakan aplikasi yang dibuat. Tahapan material collecting merupakan tahap mendata bahan-bahan yang akan digunakan pada aplikasi, seperti gambar, animasi, video, audio, dan lain-lain. Tahap assembly merupakan tahap proses membuat aplikasi didasarkan pada diagram alir yang sudah dirancang dengan memanfaatkan semua objek atau bahan multimedia yang sudah ada. Tahap testing (pengujian)merupakan tahap ini dilakukan untuk pengujian aplikasi yang sudah dibuat. Tahap ini dilakukan dengan menggunakan pengujian fungsional (pengujian alpha) pada aplikasi yang sudah dibuat, setelah itu dilakukan pengujian kepada pengguna (pengujian betha) untuk melihat 
apakah alpikasi yang dibuat sudah sesuai dengan kebutuhan pengguna. Tahap Distribution (pendistribusian), tahap ini akan dilakuakan penyimpanan aplikasi pada sebuah media penyimpanan tertentu.

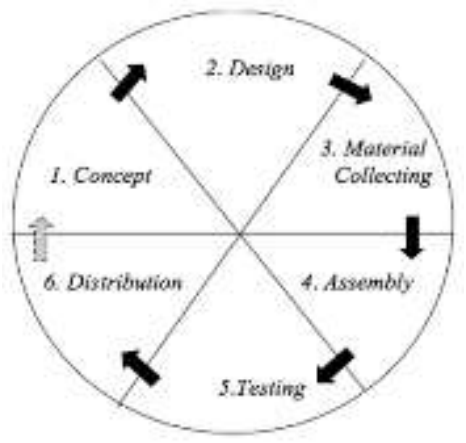

Gambar 1. Tahapan MDLC

\section{HASIL DAN PEMBAHASAN}

Dengan menggunakan metode pengembangan aplikasi yaitu MDLC, mak menghasilkan tahapan sebagai berikut :

a. Tahap Concept

Hasil dari tahapan ini adalah rumusan konsep dimana konsep aplikasi pada pembelajaran ini bertujuan untuk membuat media pembelajaran interaktif yang berfungsi sebagai alat bantu pembelajaran pelajaran ilmu pengetahuan sosial, dan pengguna aplikasi adalah guru dan siswa. Deskripsi dari aplikasi, aplikasi pembelajaran yang dibangun berbasis WEB. Data yang diolah pada aplikasi adalah data guru, data siswa, data materi, data soal, data nilai. Adapun hubungan antar data ditunjukan pada gambar 2. Gambar 2 menunjukan model entity relationship diagram (ERD) yang menunjukan bahwa user yang terlibat yaitu guru dan siswa. Guru melakukan olah materi dan soal, sedangkan siswa mengerjakan soal yang diberikan oleh guru.

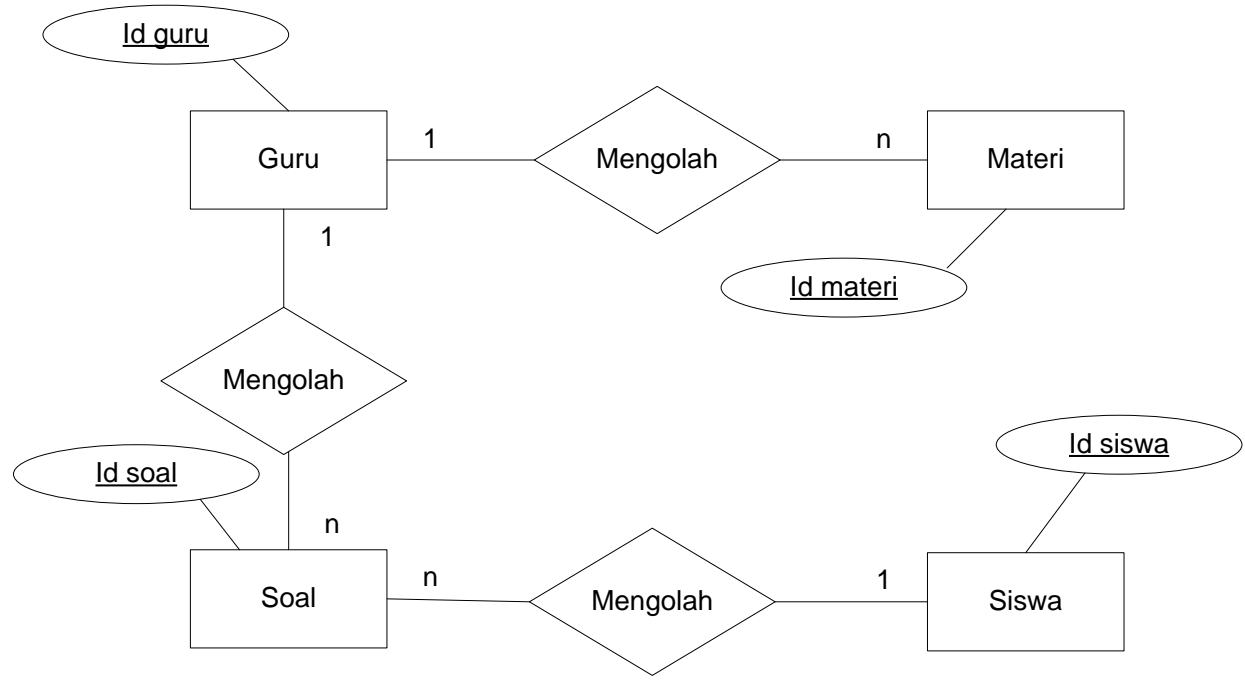

Gambar 2. Model ERD 


\section{b. Tahap Design}

Pada tahapan ini design menggunakan desain storyboard. Beberapa hasil dari desain yang telah dibuat dapat dilihat di gambar 3, 4, 5, dan 6 .

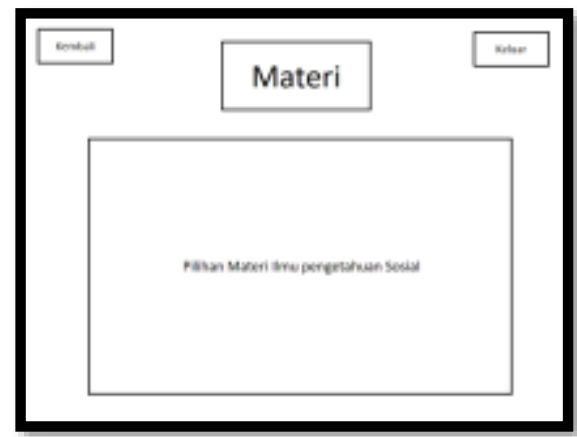

Gambar 3. Desain halaman materi

Gambar 3 menunjukan desain halaman materi , menjelaskan beberapa materi yang akan diterapkan pada aplikasi. Materi yang digunakan pada halaman ini yaitu mata pelajaran IPS kelas VII.

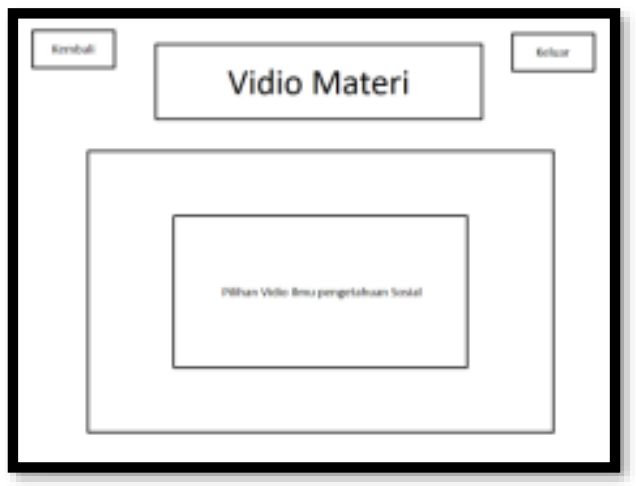

Gambar 4. Desain halaman video materi

Gambar 4 menunjukan halaman menu video materi, didalam menu ini terdapat beberapa video yang diterapkan pada aplikasi.

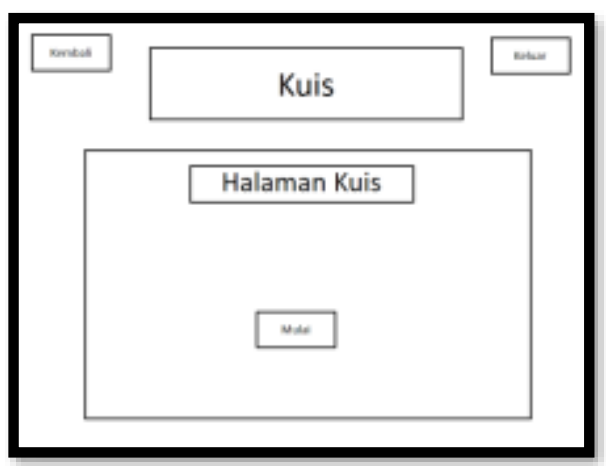

Gambar 5. Desain halaman Kuis

Gambar 5 menunjukan desain halaman kuis, pada halaman tersebut siswa melakukan kuis dengan cara memasukan nama kelas dan nis jika ingin memulai kuis dan jenis kuis yang diterapkan yaitu bentuk pilihan ganda. 


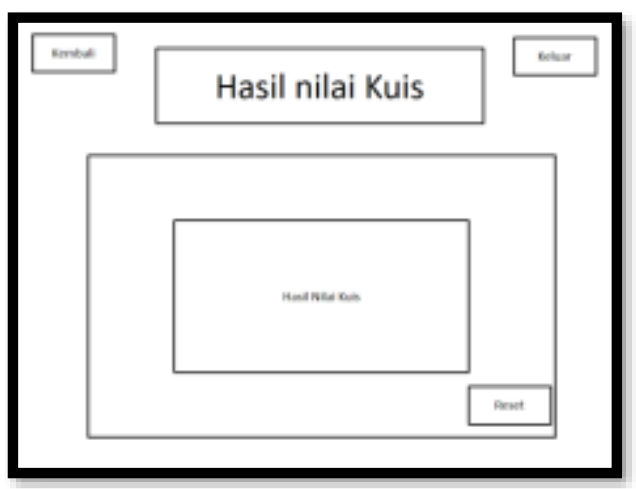

Gambar 6. Desain halaman nilai kuis

Gambar 6 menunjukan desain halaman hasil kuis, di halaman tersebut guru dapat melihat hasil kuis siswa yang sudah melakukan kuis pada halaman guru. Hasil kuis ini bentuk sementara jadi setelah ada data di hasil kuis maka guru akan mencatat hasil kuis pada catatan yang sudah disiapkan.

\section{c. Tahap material collecting}

Untuk tahap ini, proses yang dilakukan adalam mengumpulkan bahan - bahan yang terkait dengan materi pembelajaran yang didapat melalui waawncara dengan guru yang mengajar mata pelajaran ilmupengetahuan social atau bersumber dari literature yang berasal dari buku atau dari internet. Selain bahan yang berupa materi ajar, dikumpulkan juga bahan pembuatan aplikasi dalam bentuk gambar, foto, suara, dan video.

\section{d. Tahap assembly}

Pada tahap ini pembuatan aplikasi menggunakan menggunakan Software adobe flash CS 6 dan pemrograman actionscript 2.0. Gambar 7, 8, dan 9 merupakan gambar dari beberapa hasil tampilan dari desain yang sudah dibuat sebelumnya.

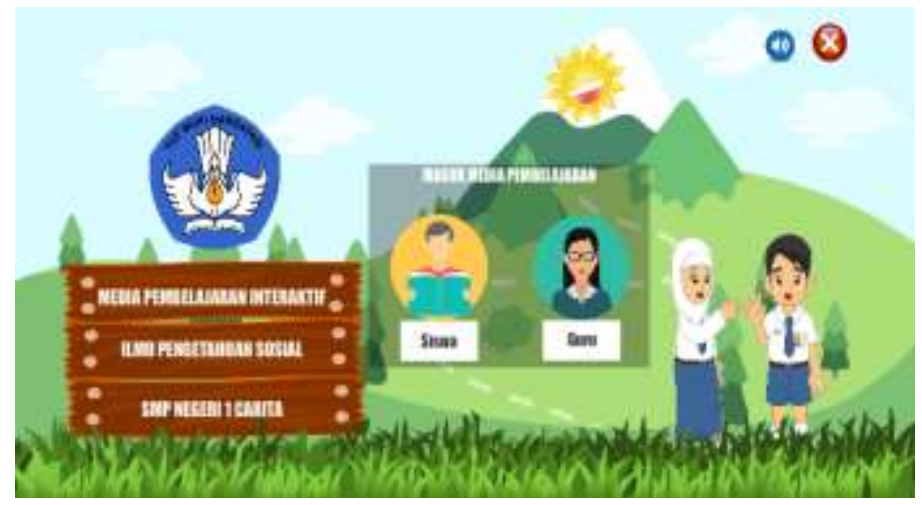

Gambar 7. Implemtasi antarmuka halaman utama

Gambar 7 menunjukan tampilan antarmuka menu halaman utama, tampilan ini digunakan untuk guru dan siswa masuk ke aplikasi dengan cara memasukan username dan password. 


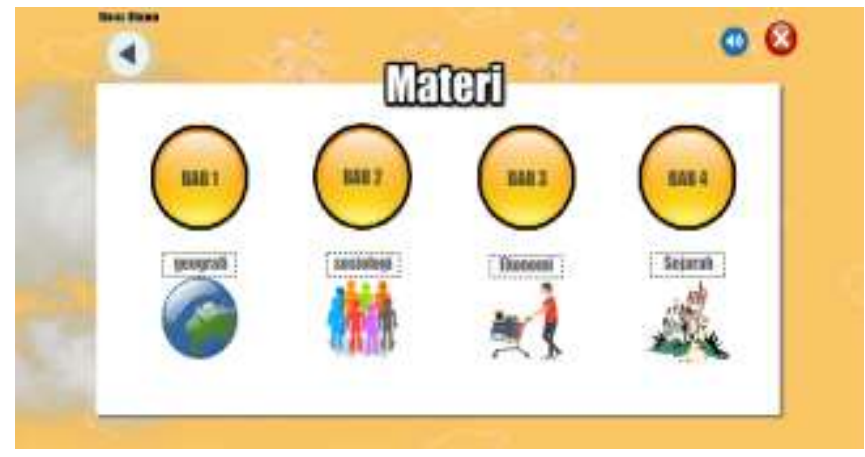

Gambar 8. Implementasi Antarmuka Halaman Materi

Gambar 8 menunjukan tampilan antarmuka menu halaman materi, pada tampilan tersebut ditunjukan beberapa materi yang diajarkan.

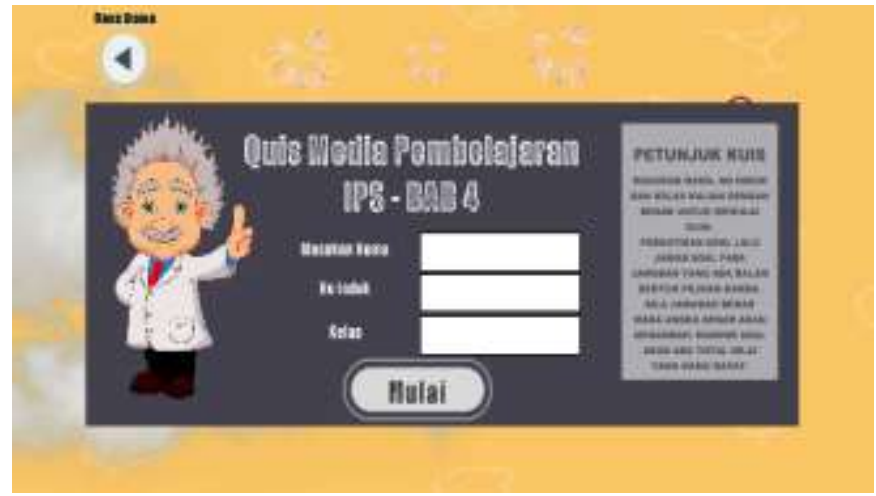

Gambar 9. Implementasi Antarmuka Halaman kuis bab 4

Gambar 9 menunjukan halaman kuis, halaman ini digunakan siswa untuk melakukan kuis di materi tertentu dengan cara terlebih dahulu memasukan nama, no indeks, dan kelas.

\section{e. Tahap Testing}

Setelah melakukan tahap assembly, maka tapahan berikutnya adalah tahap testing. Metode yang digunakan untuk pengujian alpha yaitu metode blackbox, metode ini digunakan untuk melihat apaka secara fungsional proses yang ada diaplikasi sudah berjalan atau belum [14][15]. Hasil pengujian alpha terhadap aplikasi yang dibuat dapat dilihat pada table 1, pengujian dilakukan dengan menguji apakah material yang digunakan pada setiap desain form dapat berfungsi atau tidak.

\section{Tabel 1 hasil Pengujian}

\begin{tabular}{cccc}
\hline No & Material & Pengujan & Hasil Pengujian \\
\hline \multirow{2}{*}{1} & Image / & Uji gambar di setiap gambar background & Berhasil \\
& Gambar & aplikasi & Bji gambar pada button aplikasi \\
2 & Button & Uji button pada setiap form aplikasi & Berhasil \\
3 & Video & ujipada video yang ada di aplikasi & Berhasil \\
4 & Suara & Uji suara pada latar aplikasi & Berhasil \\
& & Uji suara pada button aplikasi & Berhasil \\
\hline
\end{tabular}




\section{f. Tahap Distribition}

Tahap ini merupakan tahap akhir untuk penentuan aplikasi disimpan di media penyimpanan jenis apa. Dalam penelitian ini media penyimpananyag digunakan adalah Database Mysql. Aplikasi dalam betuk web disimpan di komputer server yang digunakan guru, dan terhubung dengan komputer client yang digunakan oleh siswa.

\section{KESIMPULAN}

Berdasarkan pengujian yang telah dilakuakn, aplikasi pembelajaran yang telah dibuat menggunakan metode MDLC sudah dapat dapat dijadikan sebagai alat bantu dalam proses pembelajar ilmu pelajaran sosial untuk guru dan siswa, dan memberikan kemudah kepada guru dan siswa dalam proses pembelajaran ilmu pengetahuan sosial.

\section{SARAN}

Saran untuk penelitian selanjutnya yaitu diharapkan dapat dikembangkan aplikasi pembelajaran interaktif yang lebih menarik lagi salah satunya menggabungkan animasi dalam bentuk 3 dimensi dan suara (dubbing). Selain itu juga dapat diterapkan model belajar yang sifatnya dinamis (dynamic learning).

\section{DAFTAR PUSTAKA}

[1] Sanjaya, Wina. 2008. Perencanaan dan Desain Sistem Pembelajaran. Jakarta: Kencana.

[2] Prawiro, S. A., \& Irawan, A. H, 2012, Perancangan Media Pembelajaran Interaktif Ilmu Pengetahuan Alam untuk Siswa Kelas 4 SD dengan Metode Learning The Actual Object. Jurnal Sains dan Seni ITS, 1(1), F28-F33.

[3] Sagala, S., 2010, Konsep dan Makna Pembelajaran. Bandung: Alfabeta

[4] Ali, M., 2009, Pengembangan media pembelajaran interaktif mata kuliah medan elektromagnetik. Jurnal Edukasi Elektro, 5(1).

[5] Arindiono, R. J., \& Ramadhani, N., 2013, perancangan media pembelajaran interaktif matematika untuk siswa kelas 5 SD. Jurnal Sains dan Seni ITS, 2(1), F28-F32.

[6] Putri Sujana, A., Nurhayati, S., \& Indriani Lestariningati, S. 2017. Sistem Aplikasi Ujian Praktikum Online Menggunakan Mini Pc Raspberry Pi. KOMPUTIKA-Jurnal Sistem Komputer, 6.

[7] Harsasi, M. 2011. Pengembangan Computer-Assisted Instruction Sebagai Bahan Ajar pada Universitas Terbuka. Prosiding Kenferensi Nasional ICT-M Politeknik Telkom (KNIP), 94.

[8] Dwi riastuti, 2009, Pengembangan computer Assisted Instruction(CAI) untuk pembelajaran biologi SMA kelas XI," Jurnal penelitian dan evaluasi pendidikan, pp. 6984

[9] Yulianto, B., Heriyanni, E., Sembiring, R. E., Amalia, R., \& Fridian, R. 2013. Aplikasi pembelajaran algoritma dasar interaktif berbasiskan Computer Assisted Instruction. ComTech: Computer, Mathematics and Engineering Applications, 4(2), 1255-1266.

[10] Binanto, I.,. 2010, Multimedia Digital- Dasar Teori dan Pengembangannya. Yogyakarta: Andi

[11] Mustika, M., Sugara, E. P. A., \& Pratiwi, M. 2018. Pengembangan Media Pembelajaran 
Interaktif dengan Menggunakan Metode Multimedia Development Life Cycle. Jurnal Online Informatika, 2(2), 121-126.

[12] Nurajizah, S. 2016. Implementasi Multimedia Development Life Cycle Pada Aplikasi Pengenalan Lagu Anak-Anak Berbasis Multimedia. PROSISKO: Jurnal Pengembangan Riset dan Observasi Sistem Komputer, 3(2).

[13] Rizal, M., Mursalim, M., \& Kamaruddin, K. (2019). Rancang Bangun Game Edukasi Vocabulary English Menggunakan Metode MDLC. Inspiration: Jurnal Teknologi Informasi dan Komunikasi, 9(1), 75-80.

[14] Suandi, A., Khasanah, F. N., \& Retnoningsih, E. (2017). Pengujian Sistem Informasi Ecommerce Usaha Gudang Cokelat Menggunakan Uji Alpha dan Beta. Information System For Educators And Professionals: Journal of Information System, 2(1), 61-70.

[15] Santoso, B. (2017). Pengujian Prototipe Sistem Informasi Pemasaran Berbasis ECommerce Dengan Pendekatan Alpha Betha. Faktor Exacta, 10(1), 90-100 